\title{
Application of TRACI and CML Modeling Tools in Life Cycle Impact Assessment of Municipal Wastes
}

\author{
Samson O. Ojoawo*, Abayomi A. Gbadamosi \\ Department of Civil Engineering, Ladoke Akintola University of Technology, Ogbomoso, Nigeria. \\ Email: *soojoawo@lautech.edu.ng
}

Received January $23^{\text {rd }}, 2013$; revised February $25^{\text {th }}, 2013$; accepted March $22^{\text {nd }}, 2013$

Copyright (C) 2013 Samson O. Ojoawo, Abayomi A. Gbadamosi. This is an open access article distributed under the Creative Commons Attribution License, which permits unrestricted use, distribution, and reproduction in any medium, provided the original work is properly cited.

\begin{abstract}
In this study, the Tool for the Reduction and Assessment of Chemical and other Environmental Impacts (TRACI) of the United States Environmental Protection Agency and the methodology of the Centre for Environmental Studies (CML) of the University of Leiden are two approaches applied as provided for in the $\mathrm{GaBi}_{5}$ (Holistic Balancing) Life Cycle Assessment (LCA) software database, to classify and characterize environmental impacts of municipal wastes in Ogbomoso South Local Government Area (LGA), Nigeria. On waste composition, 5 representative households were selected, each from the cardinal polling units in Ibapon (ward 4) for the study. Wastes samples were collected from the households over a period of 5 days, sorted, classified according to their constituents and weighed accordingly. For the Life Cycle Impact Assessment (LCIA), two waste management scenarios/models were developed and compared using $\mathrm{GaBi}_{5}$ software. Scenario 1 involves collection, transportation and landfilling, while Scenario 2 ends with incineration. The Impact Indices determined from both scenarios were: Global Warming Potential (GWP), Acidification Potential (AP), Eutrophication Potential (EP) and Ozone Layer Depletion Potential (ODP). Findings show that the overall mean percent (\%) wastes composition for biodegradable, metal, textile, paper, plastic, glass and wood were respectively found to be 55.9, 9.5, 2.4, 6.5, 6.7, 6.6, and 12.2. From the results of LCIA methods studied, landfilling of wastes poses a lesser burden on the environment, using the ODP index, as compared to incineration. It is concluded that of the management scenarios considered, landfilling of wastes is more environmentally friendly and therefore recommended for use in the study area.
\end{abstract}

Keywords: Global Warming Potential; Acidification Potential; Eutrophication Potential; Ozone Depletion Potential

\section{Introduction}

Management of solid waste has become a heterogeneous task in the $21^{\text {st }}$ century. As such, different modeling tools have been developed in this respect. The techniques has evolved over the years from Life Cycle Assessment (LCA) and statistical predictions in $1960 \mathrm{~s},[1,2]$ to modeling studies in 1970s, development of computer models in 1980s [3] and to models that included recycling and other waste management methods developed for planning of municipal solid waste management systems in the 1990s [4]. LCA has been defined as an objective process to evaluate the environmental burdens associated with a product, process or activity, by identifying and quantifying energy and materials used and waste released to the environment while evaluating and implementing

*Corresponding author. opportunities to allow environmental improvements [5].

LCA is also a method for assessing environmental burdens associated with processes or products in a "cradle to grave" fashion, i.e. from production of the raw materials to ultimate disposal of waste. LCA has been used in many studies as an environmental tool for comparative assessments of waste disposal options or management scenarios. In 1990, for example, a LCA was completed for the Council for Solid Waste Solutions, which compared the energy and environmental impacts of paper to that of plastic grocery bags. A similar study comparing disposable diapers to washable cloth diapers was also conducted. Environmental groups around the world have also adopted life cycle analysis; organizations such as Blue Angel, Green Cross, and Green Seal use and continue to improve LCA for the purpose of product labeling and evaluation. Thus, while initially limited to 
the public sector, LCA has been adopted by increasing numbers of corporations and nonprofit organizations as an aid to understanding the environmental impacts of their actions. And as demand for "green" products and pressures for environmental quality continue to mount, it is quite likely that industrial life cycle analysis will become in the 1990s what risk assessment was in the 1980s.

In another related dimension, mechanical recycling was compared with incineration in the context of LCA by [6]. It was concluded that mechanical recycling of plastics resulting from discarded TV sets in Japan is a more attractive option than incineration, which has a larger environmental burden. LCA validated the waste hierarchy for solid waste management systems in Sweden, [7] and [8]; determined the environmental load of food product consumption and processing [9-11]; and assured the feasibility of recycling rather than landfilling wasted materials in small urban communities [12]. In addition, [13] performed a comparative assessment of solid waste management Scenarios for the State of Kuwait with the revelation that the recycling stage of all the three scenarios have the highest environmental burdens while anaerobic digestion process was reported to have lowest contribution to global warming.

Other waste management models developed beyond 1990s encapsulate economics, environmental, and demographic factors. Some included population studies with system dynamics [14]; Linear programming using Excel-Visual Basic [15]; use of Decision Support Systems [16,17]; application of Fuzzy Logic [18]; Eco-indicator [19]; and the use of Multi Criteria Decision-Making techniques [20].

Different methods are being used to perform a Life Cycle Impact Assessment (LCIA). The Tool for the Reduction and Assessment of Chemical and other Environmental Impacts (TRACI) and the methodology of the Centre for Environmental Studies, University of Leiden (CML) are two methods notably being used to classify and characterize environmental impacts into the problem-oriented approach (mid point) and the damage-oriented approach (end point). TRACI is a problem-oriented method is developed by the US Environmental Protection Agency (EPA). In the problem-oriented approach flows are classified as belonging to environmental impact categories to which they contribute. The damage-oriented methods also start with classifying a system's flows into various impact categories, but the impact categories are also grouped to belong to end-point categories as damage to human health, damage to ecosystem quality or damage to resources. CML method on the other hand focuses on a series of environmental impact categories expressed in terms of emissions to the environment. The CML method includes classification, characterization, and normaliza- tion. With the help of the CML and TRACI methods more than a thousand substances are classified and characterized according to the extent to which they contribute to a list of environmental impact categories [21].

The results of the Life Cycle Inventory (LCI) phase include many different emissions. After the relevant impact categories are selected, the LCI results are assigned to one or more impact categories. If substances contribute to more than one impact category, they must be classified as contributors to all relevant categories [21]. Characterization describes and quantifies the environmental impact of the analyzed product system. After assigning the LCI results to the impact categories, characterization factors have to be applied to the relevant quantities. The characterization factors are included in the selected impact category methods like TRACI or CML. These LCI results are further converted into reference units using characterization factors. For example, a reference substance for the impact category "Global Warming Potential" (GWP) is $\mathrm{CO}_{2}$ and the reference unit is defined as $\mathrm{kg} \mathrm{CO}_{2}$-equivalent. All emissions that contribute to global warming are converted to $\mathrm{kg} \mathrm{CO}_{2}-$ equivalents according to the relevant characterization factor. Each emission has its own characterization factor. Another impact index is the "Acidification Potential" $(A P)$ which is defined as the number of $\mathrm{H}^{+}$ions produced per $\mathrm{kg}$ substance relative to $\mathrm{SO}_{2}$. What acidifying pollutants have in common is that they form acidifying $\mathrm{H}^{+}$ions. A pollutant's potential for acidification can thus be measured by its capacity to form $\mathrm{H}^{+}$ions. "Eutrophication Potential" (EP) reference is measured in term of $\mathrm{kg}$ Phosphate equivalent while the "Ozone Depletion Potential" (ODP) impact is determined in form of $\mathrm{kg}$ CFCs and $\mathrm{NO}_{\mathrm{x}}$-equivalent.

This study applies both the TRACI and CML methods of LCA to determine the environmental impacts of municipal solid wastes emanating from Ogbomoso South LGA, Nigeria. The study area is one of the two LGAs in Ogbomoso city, the other is Ogbomoso North LGA. Ogbomoso is located approximately on longitude $4^{\circ}$ East and latitude $8^{\circ} 07^{\prime}$ North. It is the second largest city in Oyo State. It is about 57 kilometers South West of Ilorin, $104 \mathrm{~km}$ North East of Oyo and $58 \mathrm{~km}$ North West of Osogbo [22]. The climate of the study area is characterized by a fairly high, uniform temperature, moderately heavy seasoned rainfall and high relative humidity. The average temperature is $26.2^{\circ} \mathrm{C}$. The lowest temperature is experienced in August, which has a mean temperature of $24.3^{\circ} \mathrm{C}$ while March has the highest with a mean temperature of $28.7^{\circ} \mathrm{C} \mathrm{[23].} \mathrm{The} \mathrm{study} \mathrm{area} \mathrm{has} \mathrm{a} \mathrm{population}$ of 100,815 people [24], and has often been described as a commercial and manufacturing centre situated in an agricultural region producing food crops like yam, cassava, corn, tobacco, cotton, etc. [25]. 
The specific objectives of this study include: determination of the amount of solid waste generated per capital in the study area; comparative assessment of waste disposal options or management scenarios and the assessment of environmental burdens associated with solid wastes.

\section{Methodology}

The two (2) main approaches to this study were field work and software application. The field work was carried out to determine the waste composition and per capita waste generation of the study area. Five (5) households were selected, one from each of the cardinal Polling Units in Ibapon (ward 4) of the LGA under study. Wastes samples were collected from the households over a period of 5 days, sorted, classified according to their constituents and weighed accordingly. The field data obtained was then fed into the $\mathrm{GaBi}_{5}$ LCIA software through the two scenarios/models developed.

The LCA methodology was employed in conducting an environmental comparison of the alternative scenarios to the current waste management system. This evaluation was conducted according to ISO 14040 that an LCA comprises four major stages: goal and scope definition, life cycle inventory, life cycle impact analysis and interpretation of the results. Figure 1 refers.

The following are the specific components of the LCA methodology adopted:

\section{1) Goal and Scope Definition}

The aim of this study is to select an optimum waste management system for Ogbomoso by evaluating, from an environmental point of view, a number of possible waste management scenarios. It is thought that the results of the study would be helpful for the Metropolitan municipality and sub-municipalities of Ogbomoso South Local Government Area of Oyo State of Nigeria.

\section{2) Functional Unit}

The functional unit adopted for this study is defined as

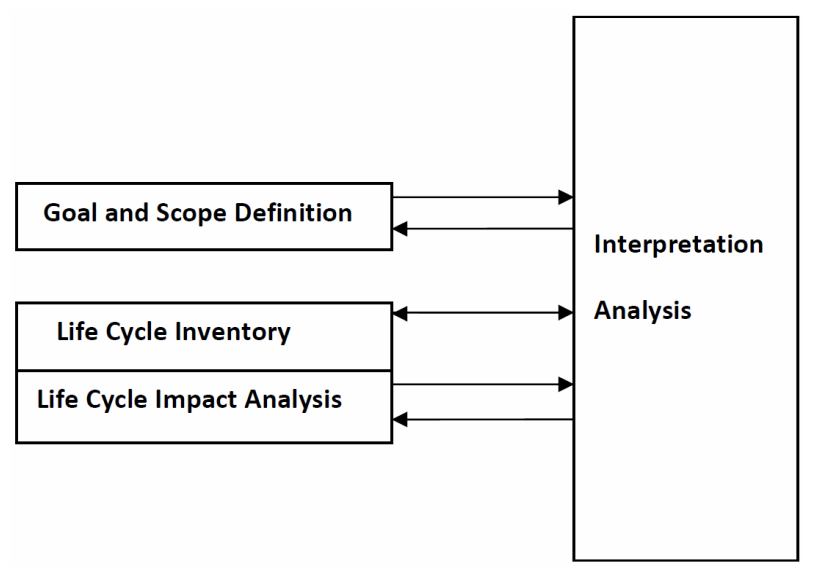

Figure 1. Phases of life cycle analysis. the amount of MSW generated in 5 household over a period of 5 days in ward 4 Ibapon area of Ogbomoso South Local Government Area.

\section{3) System Boundaries}

In this study, the solid waste materials are categorized as: paper, biodegradable, plastics, glass, metal, wood, and textile. Food waste and animal faeces are categorized as biodegradable. Aluminum, iron, tin, steel and other metallic materials are categorized as metal. Wood wastes include agricultural waste, discarded planks and discarded furniture. Any other waste that does not belong to any of the stated category is simply discarded and not considered (Figure 2 refers). The environmental impact assessment is calculated in term of: GWP $(\mathrm{kg} \mathrm{CO}$ equivalent), AP ( $\mathrm{kg} \mathrm{SO}$ equivalent), $\mathrm{EP}$ ( $\mathrm{kg}$ phosphorus equivalent), and OD (R11 equivalent).

4) Life Cycle Inventory (LCI)

The data for LCI was gathered from the selected residential houses in the study area as accommodated in the modified database of $\mathrm{GaBi}_{5}$.

\section{5) Treatment Options}

The designed treatment options $(\mathrm{T})$ for this study include: Landfilling (T1) and Incineration (T2).

Incineration option is to be considered in one of the scenarios. Atmospheric emissions from the incineration of solid waste were calculated using the $\mathrm{GaBi}_{5}$ software database. Landfill processes for the scenarios was equally performed using the same database.

6) Waste Collection and Transport

Waste samples were collected by designating bags at each of the selected household within the study area. For the purpose of this study, it is assumed that all the treatment facilities to be used are situated around Ladoke Akintola University of Technology, Ogbomoso approximately $10 \mathrm{~km}$ from the study area.

\section{7) Design of Scenarios}

The two scenarios designed to be considered in this study are illustrated in Figure 3. The first scenario consists of three main steps: Collection (C), Transportation (T), and Landfilling (L) of solid waste. The other scenario is C: Collection, L: Landfilling, T: Transportation, I: Incineration, and $(\rightarrow)$ input/output.

8) Life Cycle Impact Assessment (LCIA)

LCIA identifies and evaluates the amount and significance of the potential environmental impacts arising from the LCI. The inputs and outputs are first assigned to impact categories and their potential impacts quantified according to characterization factors. For example: GWP $11.3 \mathrm{~kg} \mathrm{CO} * 1 ; 3 \mathrm{~kg} \mathrm{CO} * 3 ; 6 \mathrm{~kg} \mathrm{CH}_{4} * 25$ gives $160.3 \mathrm{~kg}$ $\mathrm{CO}_{2}$ equivalent. Also, AP $0.001 \mathrm{~kg} \mathrm{SO} * 1 ; 0.08 \mathrm{~kg} \mathrm{NO}$ $* 0.7 ; 0.9 \mathrm{~kg} \mathrm{HCl} * 0.88$ gives $0.849 \mathrm{~kg} \mathrm{\textrm {SO } _ { 2 }}$ equivalent. LCIA involves several steps according to the ISO 14044 standard. Within the scope of a study certain elements 


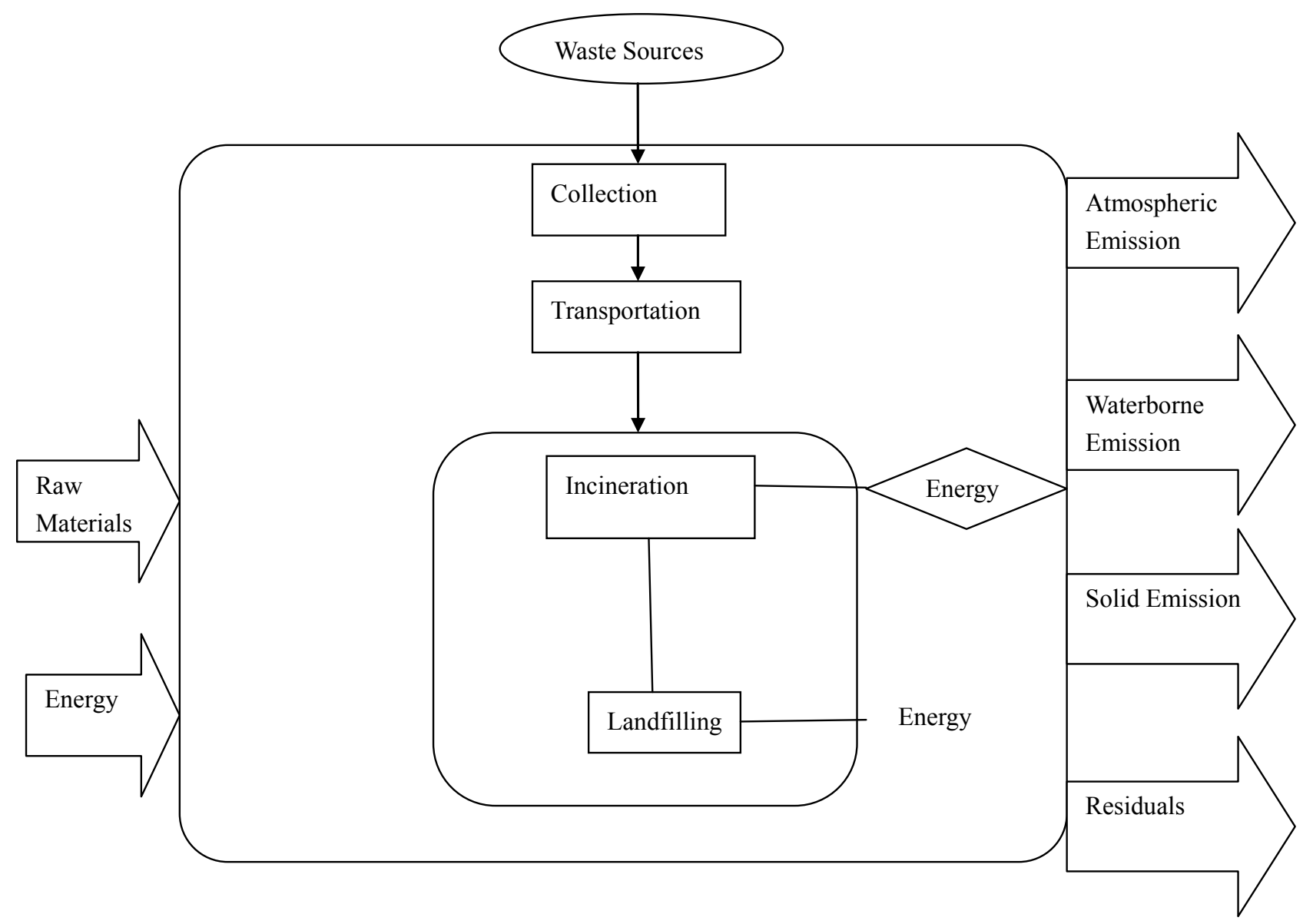

Figure 2. The system boundary.

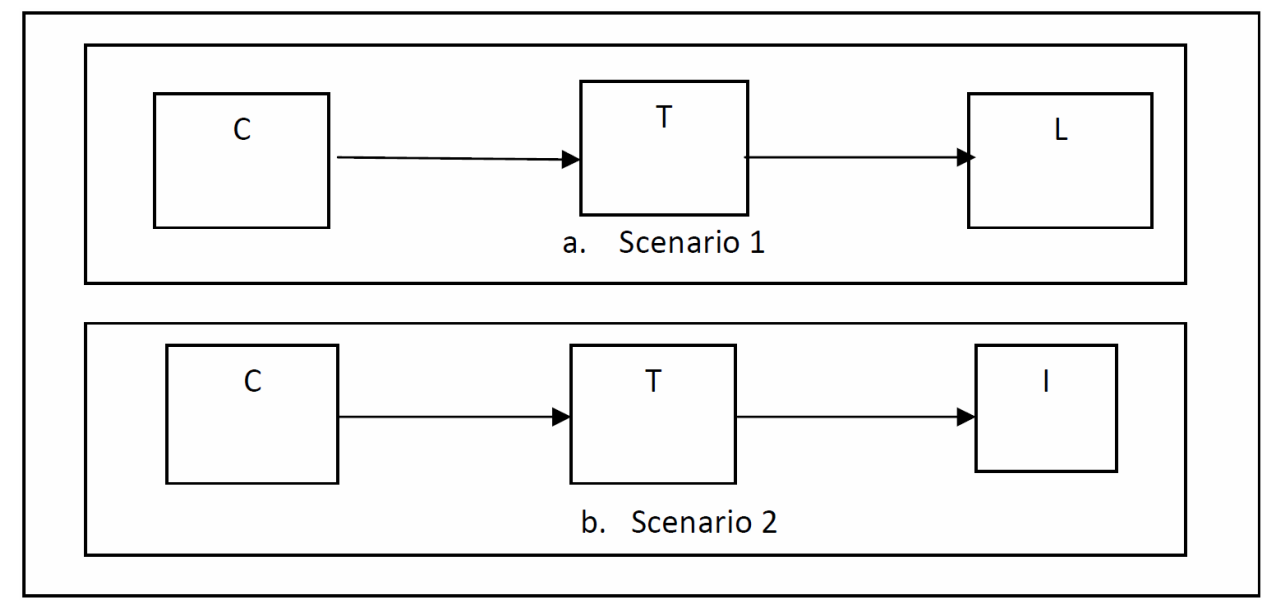

Figure 3. The scenarios of MSW employed.

are defined for the LCIA. Mandatory elements include the selection of relevant impact categories, classification and characterization. The optional elements of the study are normalization, grouping and weighting (PE-International, 2011).

9) Data Collection

Both primary and secondary data were employed in this study. Primary data were generated from the analysis of the actual waste parameters in the study area while secondary data were those from the findings of previous researchers and slightly modified as databases in the GaBi programme.

10) GaBi Software

For this study, the computer program $\mathrm{GaBi}_{5}$ has been 
utilised. GaBi software has been developed in accordance with the ISO 14040 and ISO 14044 standards and allows for managing and storing the necessary data, as well as performing the calculations and required sensitivity tests.

\section{1) Scenario One}

The first scenario include collection (C), transportation (T) and landfilling (L). The LCA modelling is achieved using plan, process and flow. The plan represent the system boundary of the LCA, process represent real life activities in the life cycle of the product being analysed (e.g. transportation), while flow represent the materials and energy in the system. The flow in the model follows the direction of the arrow as shown in Figure 4.

12) Scenario Two

In the sencond scenario, collection (C); transportation (T); and incineration (I) were considered. The flow within the system is in the direction of the arrow. The composition by mass of each waste category is shown (in $\mathrm{kg}$ ) on Figure 5.

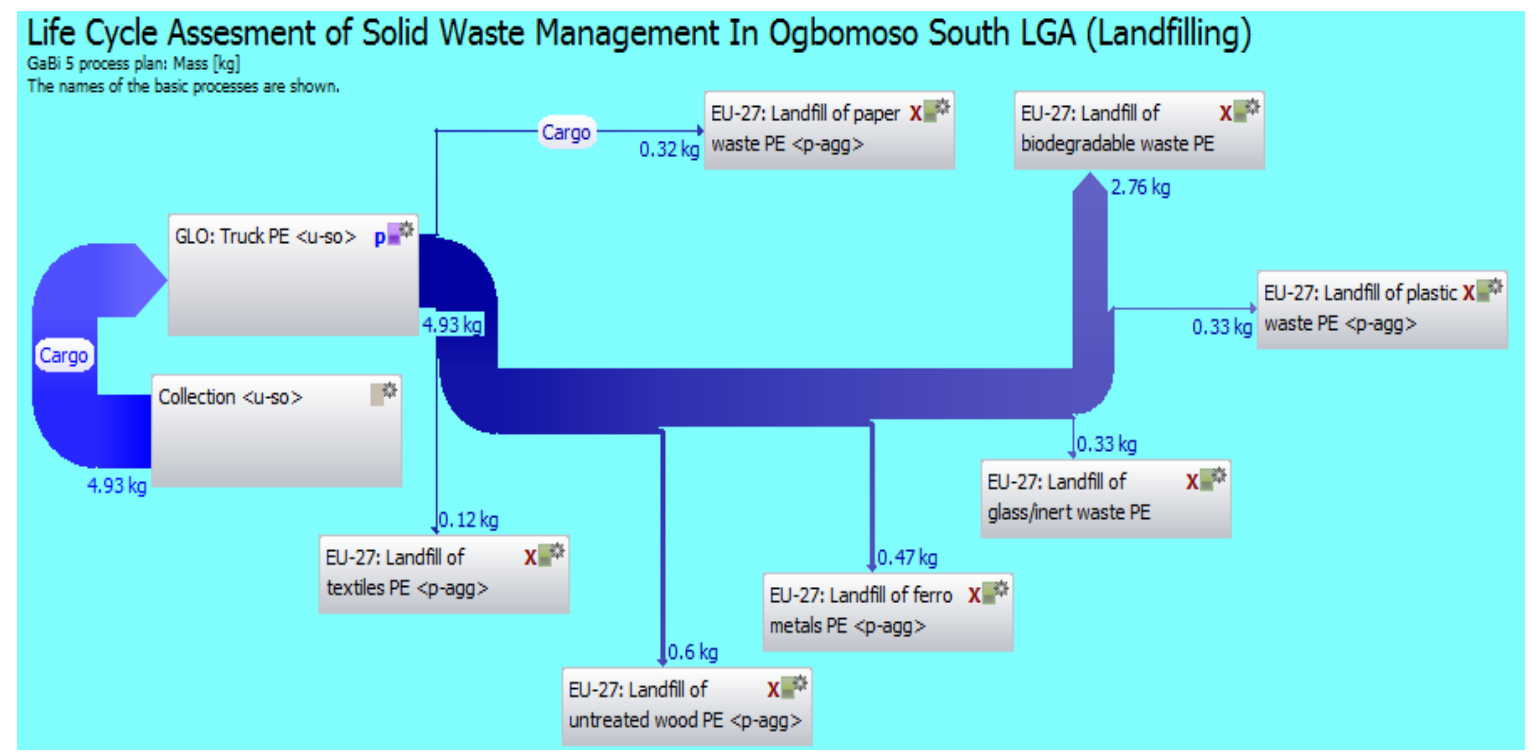

Figure 4. LCA scenario/model one of waste management developed using $\mathrm{GaBi}_{5}$ software.

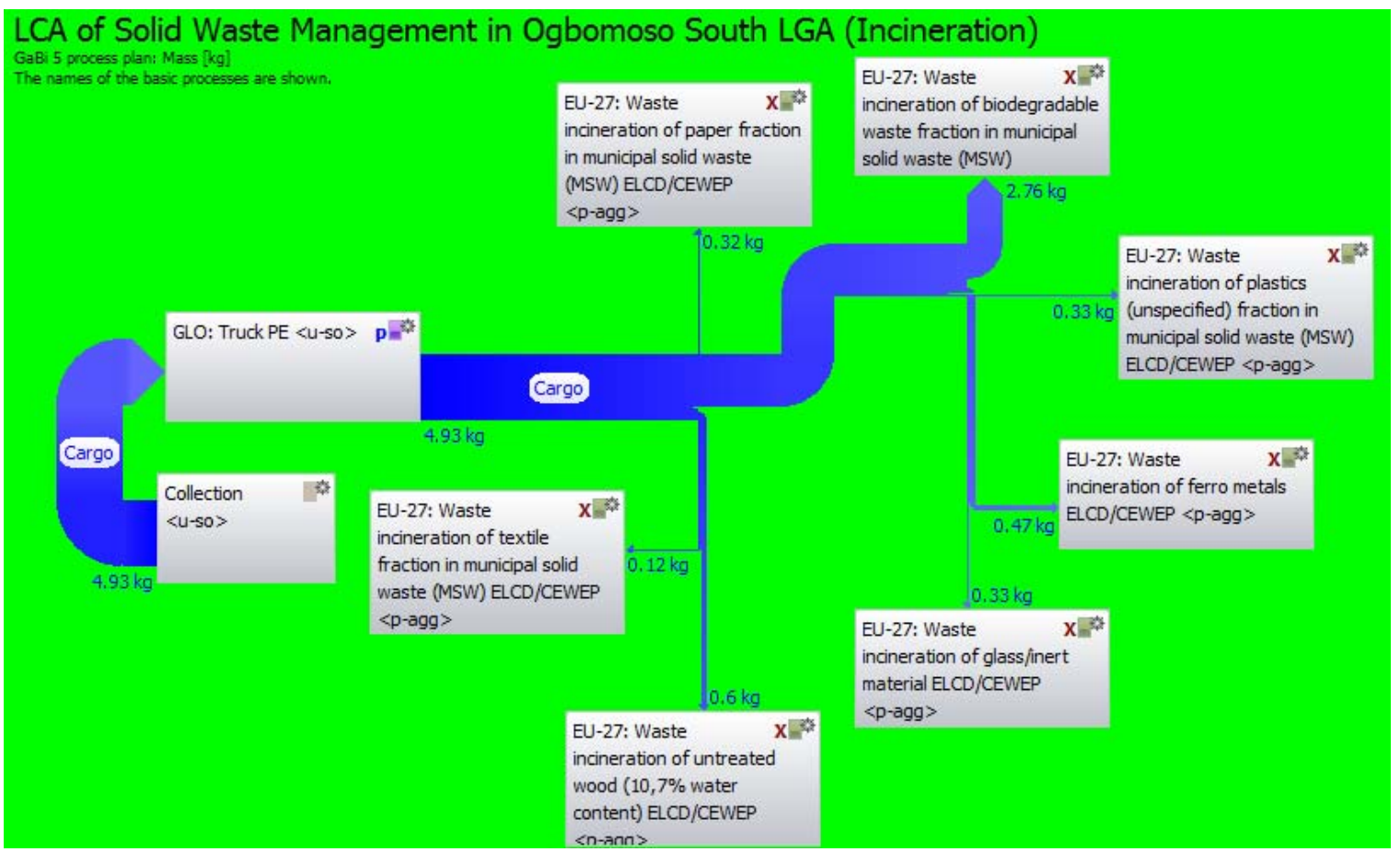

Figure 5. LCA scenario/model two of waste management developed using $\mathrm{GaBi}_{5}$ software. 


\section{Results and Discussion}

\subsection{Composition of Waste by Mass from Selected Households in the Study Area}

In Table 1, H1 - H5 are the 5 representative households within the study area. H1: Ile Agbala; H2: Ile Dansi; H3: Ile Atere; H4: Ile Ibapon; H5: Ile Bakoko. Food wastes and animal feaces were categorised as biodegradable waste. Aluminium, iron, steel, tin and other metallic materials were categorised as metal, Wood waste included discarded timber, broken furnitures and agricultural wastes.

The population of the selected household ranges between 6 and 14 occupants. Assuming an average population of 10 occupants per household, therefore the waste per capita per day is estimated as follows:
Per capita waste generation per day $=\sum$ of Average waste/Avr. Population $=4.93 / 10=0.49 \mathrm{~kg}$ per capita per day

The result shows that biodegradable wastes has contributes mostly, nearly $60 \%$ to the overall composition, followed by wood, metal, plastic, glass, paper and textile respectively in that order. The quantity of wastes for incineration was found to be about a third of the entire wastes of the study area.

\subsection{Life Cycle Inventory (LCI)}

The inventory analysis of the study includes data compilation, quantification and analysis based on both the TRACI and CML methods, the results of which is as shown in Tables 2-5 below.

Table 1. Waste composition by mass.

\begin{tabular}{|c|c|c|c|c|c|c|c|}
\hline Waste Materials (kg) & H1 & $\mathrm{H} 2$ & H3 & $\mathrm{H} 4$ & H5 & Average & $\%$ waste composition \\
\hline Occupant's Population & 6 & 9 & 10 & 11 & 14 & 10 & \\
\hline Paper (kg) & 0.20 & 0.25 & 0.27 & 0.45 & 0.42 & 0.32 & 6.49 \\
\hline Biodegradable (kg) & 2.75 & 2.76 & 2.47 & 2.53 & 3.29 & 2.76 & 55.98 \\
\hline Plastic (kg) & 0.32 & 0.25 & 0.26 & 0.38 & 0.43 & 0.33 & 6.69 \\
\hline Glass (kg) & 0.20 & 0.29 & 0.26 & 0.59 & 0.31 & 0.33 & 6.69 \\
\hline Metal (kg) & 0.21 & 0.39 & 0.52 & 0.48 & 0.74 & 0.47 & 9.53 \\
\hline Wood (kg) & 0.40 & 0.50 & 0.36 & 0.95 & 0.77 & 0.60 & 12.17 \\
\hline Textile (kg) & 0.00 & 0.00 & 0.14 & 0.18 & 0.30 & 0.12 & 2.43 \\
\hline Total (kg) & 4.08 & 4.44 & 4.28 & 5.56 & 6.26 & 4.93 & 100.00 \\
\hline
\end{tabular}

Table 2. LCI for scenario/model one using TRACI.

\begin{tabular}{|c|c|c|c|c|c|c|c|c|}
\hline Method & Impact Category & Biodegr-Adable & Metal & Glass & Paper & Plastic & Textile & Wood \\
\hline \multirow[t]{4}{*}{ TRACI } & GWP-100 years ( $\mathrm{kg} \mathrm{CO}_{2}$ eqv.) & 2.48 & 0.0093 & 0.0046 & 0.463 & 0.0243 & 0.178 & 1.3 \\
\hline & $\mathrm{AP}\left(\mathrm{kg} \mathrm{SO} \mathrm{S}_{2}\right.$ eqv. $)$ & 0.0503 & 0.0015 & 0.00166 & 0.00722 & 0.00387 & 0.00274 & 0.0169 \\
\hline & EP (kg phosphate eqv.) & 0.00209 & $1.07 \mathrm{E}-005$ & $2.21 \mathrm{E}-006$ & $7.2 \mathrm{E}-005$ & $4.09 \mathrm{E}-005$ & 0.000116 & $6.08 \mathrm{E}-005$ \\
\hline & ODP (kg RII eqv.) & $7.2 \mathrm{E}-010$ & $1.31 \mathrm{E}-011$ & $4.54 \mathrm{E}-012$ & $8.34 \mathrm{E}-011$ & $8.6 \mathrm{E}-011$ & $3.13 \mathrm{E}-011$ & $1.56 \mathrm{E}-010$ \\
\hline
\end{tabular}

Table 3. LCI for scenario/model one using CML.

\begin{tabular}{|c|c|c|c|c|c|c|c|c|}
\hline Method & Impact Category & Biodegr-Adable & Metal & Glass & Paper & Plastic & Textile & Wood \\
\hline \multirow[t]{4}{*}{ CML } & GWP-100 years (kg CO 2 eqv.) & 2.63 & 0.00966 & 0.00461 & 0.492 & 0.0246 & 0.189 & 1.38 \\
\hline & $\mathrm{AP}\left(\mathrm{kg} \mathrm{SO} \mathrm{S}_{2}\right.$ eqv. $)$ & 0.00083 & $2.22 \mathrm{E}-005$ & $2.81 \mathrm{E}-0.05$ & 0.000116 & $7.13 \mathrm{E}-0.05$ & $4.39 \mathrm{E}-005$ & 0.000263 \\
\hline & EP(kg phosphate eqv.) & 0.00488 & 0.000188 & $3.85 \mathrm{E}-006$ & 0.00017 & $8.77 \mathrm{E}-005$ & 0.000284 & 0.000144 \\
\hline & ODP (kg RII eqv.) & $7.2 \mathrm{E}-010$ & $1.31 \mathrm{E}-011$ & $4.54 \mathrm{E}-012$ & $8.34 \mathrm{E}-011$ & $8.61 \mathrm{E}-011$ & $3.13 \mathrm{E}-011$ & $1.56 \mathrm{E}-010$ \\
\hline
\end{tabular}

Table 4. LCI for scenario/model two using TRACI.

\begin{tabular}{|c|c|c|c|c|c|c|c|c|}
\hline Method & Impact Category & Biodegradable & Metal & Glass & Paper & Plastic & Textile & Wood \\
\hline \multirow[t]{3}{*}{ TRACI } & GWP-100 years (kg CO $\mathrm{CO}_{2}$ eqv.) & 1.87 & -0.366 & 0.0204 & 0.342 & 0.752 & 0.179 & 0.981 \\
\hline & EP (kg phosphate eqv.) & $9.15 \mathrm{E}-005$ & $-3.93 E-006$ & $4.1 \mathrm{E}-006$ & $5.49 \mathrm{E}-006$ & $1.02 \mathrm{E}-005$ & $9.04 \mathrm{E}-006$ & $8.66 \mathrm{E}-006$ \\
\hline & ODP (kg RII eqv.) & $9.33 \mathrm{E}-009$ & $1.88 \mathrm{E}-008$ & $9.81 \mathrm{E}-010$ & $2.83 \mathrm{E}-010$ & $9.43 \mathrm{E}-010$ & $3.69 \mathrm{E}-010$ & $1.74 \mathrm{E}-009$ \\
\hline
\end{tabular}


Table 5. LCI for scenario/model two using CML.

\begin{tabular}{cccccccccc}
\hline Method & Impact Category & Biodegr-Adable & Metal & Glass & Paper & Plastic & Textile & Wood \\
\hline \multirow{2}{*}{ CML } & GWP-100 years (kg CO 2 eqv.) & 1.87 & -0.366 & 0.0205 & 0.342 & 0.752 & 0.179 & 0.981 \\
\hline \multirow{2}{*}{ AP (kg SO 2 eqv.) } & 0.00127 & -0.00126 & $4.72 \mathrm{E}-005$ & $4.48 \mathrm{E}-005$ & 0.000131 & 0.000109 & 0.000139 \\
EP (kg phosphate eqv.) & 0.000246 & -0.000106 & $1.13 \mathrm{E}-005$ & $1.49 \mathrm{E}-005$ & $2.73 \mathrm{E}-005$ & $2.44 \mathrm{E}-005$ & $2.33 \mathrm{E}-005$ \\
ODP (kg RII eqv.) & $8.8 \mathrm{E}-009$ & $1.77 \mathrm{E}-008$ & $9.24 \mathrm{E}-010$ & $2.67 \mathrm{E}-010$ & $8.92 \mathrm{E}-010$ & $3.48 \mathrm{E}-010$ & $1.64 \mathrm{E}-009$ \\
\hline
\end{tabular}

\subsection{Life Cycle Impact Assessment (LCIA)}

Figures 6-21 presents the results of the LCIAs of the two scenarios/models using both TRACI and CML methods. The Environmental Impact indices are GWP, AP, EP and ODP.

1) For Scenario One Using TRACI Method

Using the TRACI method in GaBi database, The results from Figures 6-9 can be summarised as follows:

GWP: Biodegradable $>$ wood $>$ paper $>$ textile $>$ plastic > metal > glass;

AP: Biodegradable $>$ wood $>$ paper $>$ plastic $>$ textile $>$ glass > metal;

EP: Biodegradable $>$ textile $>$ paper $>$ wood $>$ plastic $>$ metal > glass;

ODP: Biodegradable $>$ wood $>$ plastic $>$ paper $>$ textile $>$ glass $>$ metal.

From all the indices, biodegradable materials contribute the highest environmental impact. Food, as the dominating waste here, could be responsible for this trend.

2) For Scenario One Using CML Method

Figures 10-13 below show the results and the findings therefrom can be summarised as follows:

GWP: Biodegradable $>$ wood $>$ paper $>$ textile $>$ plastic > metal > glass;

AP: Biodegradable $>$ wood $>$ paper $>$ plastic $>$ textile $>$ glass > metal;

EP: Biodegradable $>$ textile $>$ metal $>$ paper $>$ wood $>$ plastic > glass;

ODP: Biodegradable $>$ wood $>$ plastic $>$ paper $>$ textile $>$ metal $>$ glass.

Biodegradable matters also constitute the highest impact as observed in the previous method except that glass has the least noticable impact with CML method on landfilling. Since landfilling is unsuitable for metal and glass disposal, the trend observed is justifiable.

\section{3) For Scenario Two Using TRACI Method}

Using the TRACI method in GaBi database, The results from Figures 14-17 can Be summarised as follows:

GWP: Biodegradable $>$ wood $>$ plastics $>$ paper $>$ textile $>$ glass $>$ metal;

AP: Biodegradable $>$ wood $>$ plastics $>$ textile $>$ glass $>$ paper > metal;

EP: Biodegradable $>$ plastics $>$ textile $>$ wood $>$ paper $>$ glass > metal;
ODP: Metal $>$ biodegradable $>$ wood $>$ plastics $>$ glass $>$ textile $>$ paper.

Here, all the impact indices except ODP indicate biodegradable wastes as having the highest contribution. Metal however, has the lowest contribution to the GWP, $\mathrm{AP}$, and $\mathrm{EP}$ of this scenario.

4) For Scenario Two Using CML Method

The detail results are as presented in Figures 18-21. The summaries are as stated below:

GWP: Biodegradable $>$ wood $>$ plastics $>$ paper $>$ textile $>$ glass $>$ metal;

AP: Biodegradable $>$ wood $>$ plastics $>$ textile $>$ glass $>$ paper > metal;

EP: Biodegradable $>$ plastics $>$ textile $>$ wood $>$ paper $>$ glass $>$ metal;

ODP: Metal $>$ biodegradable $>$ wood $>$ glass $>$ plastics $>$ textile $>$ paper.

The result trend is practically same as of the TRACI method for this scenario. It shows that Biodegradable components dominate in the GWP, AP and EP impact indices while metals have the least influence in all cases aside the ODP having paper.

Table 6 gives the summary of the findings. Generally, scenario one (Collection; Transportation; Landfilling), using TRACI method, gives the overall respective values for GWP $\left(\mathrm{CO}_{2}\right.$ equiv.), $\mathrm{AP}\left(\mathrm{SO}_{2}\right.$ equiv.), $\mathrm{EP}$ (phosphate equiv.) and ODP as 4.76, 0.11, 2.425E-3, and 2.162E-13. Using the CML method, the overall values for GWP, AP, $\mathrm{EP}$, ODP are given as $4.76,1.676 \mathrm{E}-3,5.833 \mathrm{E}-3$, $1.095 \mathrm{E}-9$ and respectively. In Scenario two (Collection; Transportation; Incineration), using TRACI method in the GaBi database, the overall result for GWP $\left(\mathrm{CO}_{2}\right.$ equiv.), $\mathrm{AP}\left(\mathrm{SO}_{2}\right.$ equiv.), $\mathrm{EP}$ (phosphate equiv.) and ODP is given as $3.7,0.07,1.075 \mathrm{E}-4$, and $1.928 \mathrm{E}-8$ respectively. CML method in this scenario gives the overall results for GWP ( $\mathrm{CO}_{2}$ equiv.), AP ( $\mathrm{SO}_{2}$ equiv.), EP (phosphate equiv.) and ODP as 3.8, 0.67E-3, 2.931E-4, and $3.058 \mathrm{E}-8$ respectively. For both the TRACI and CML methods indicated values of the GWP, AP, and EP of landfilling as exceeding those of incineration. In the same vein, the ODP values of incineration in the two methods exceed those of landfilling. The landfilling scenario was therefore found to pose lesser ODP threat than the incineration. 


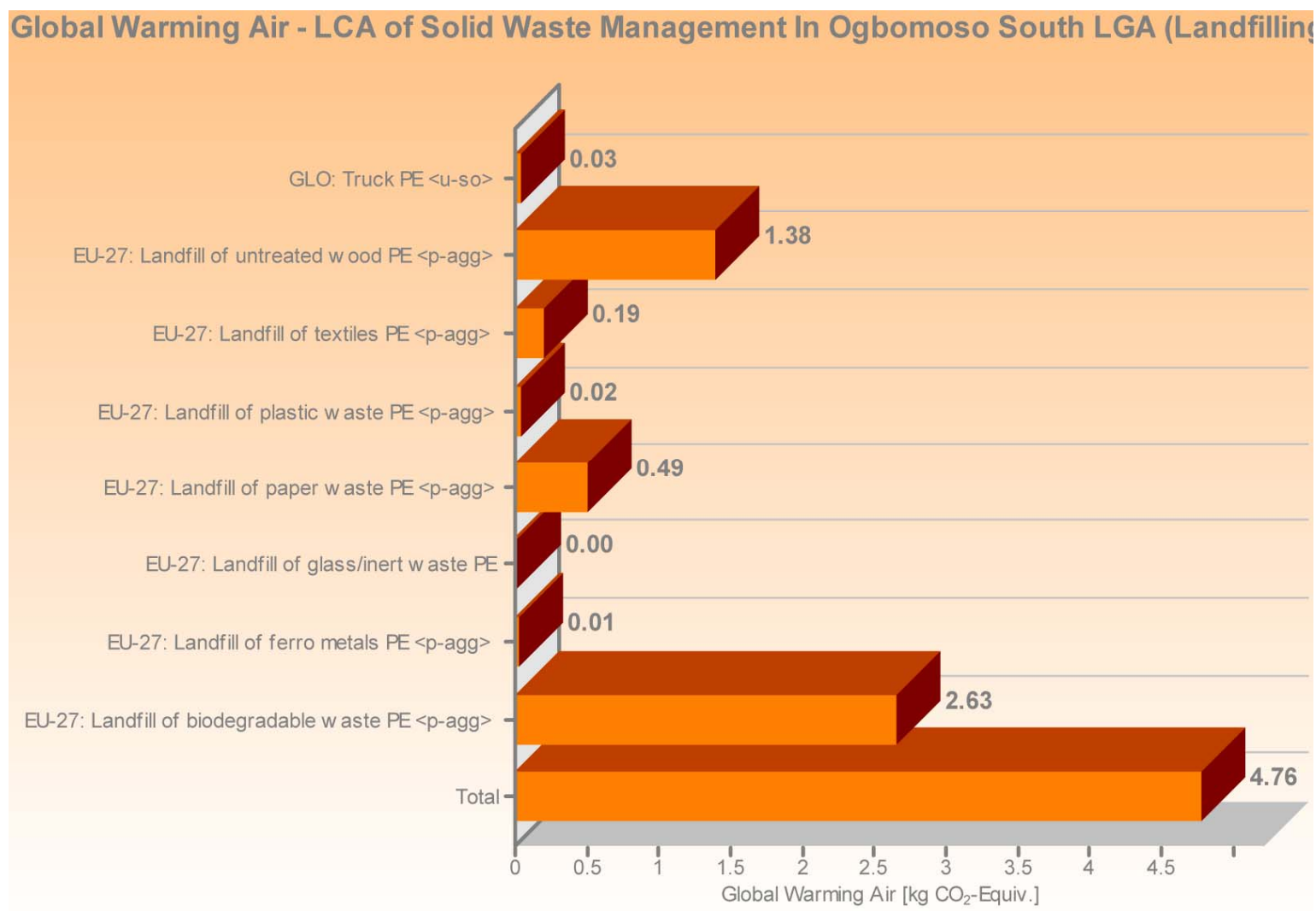

Figure 6. LCIA for landfilling (TRACI-GWP).

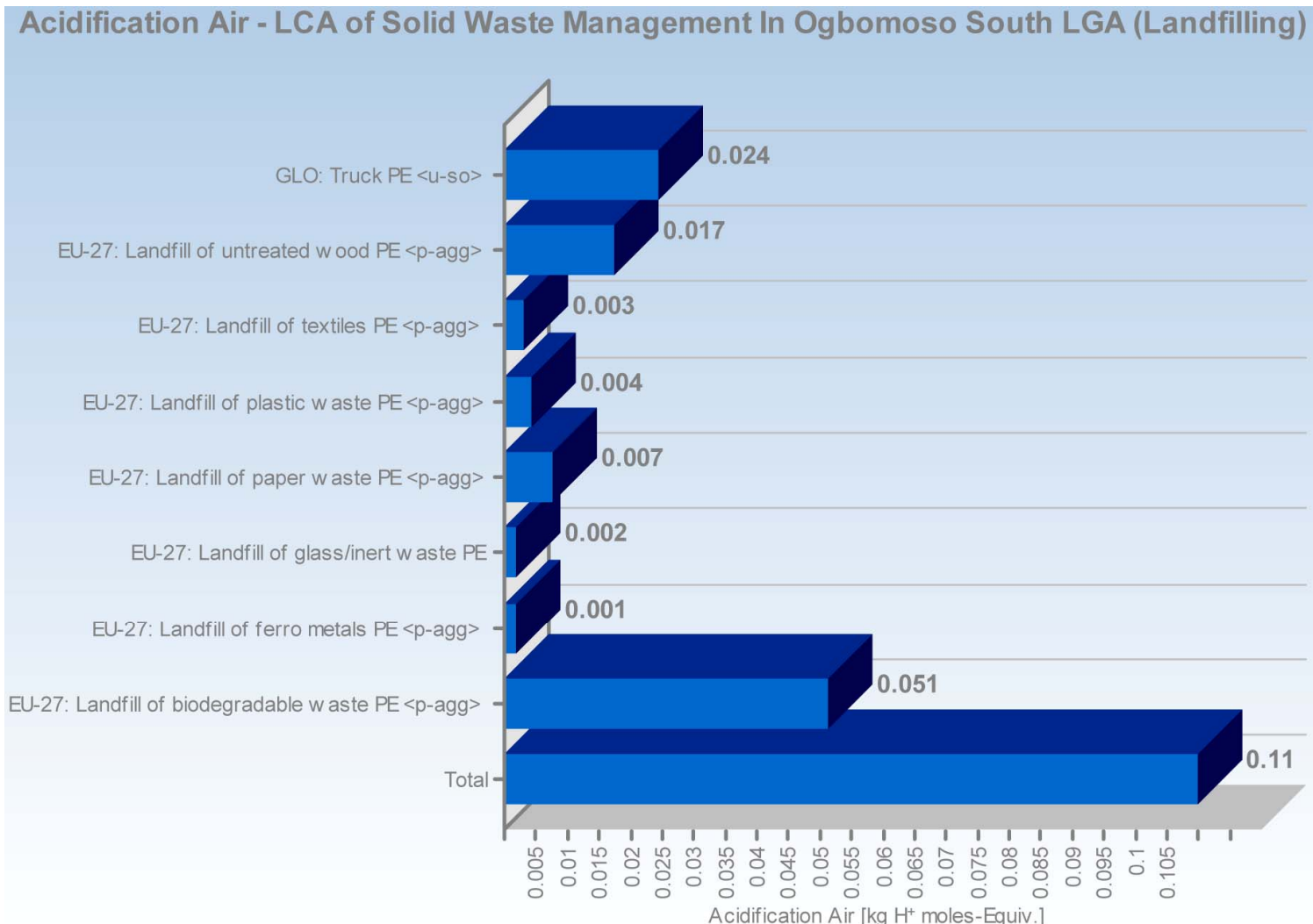

Figure 7. LCIA for landfilling (TRACI-AP). 


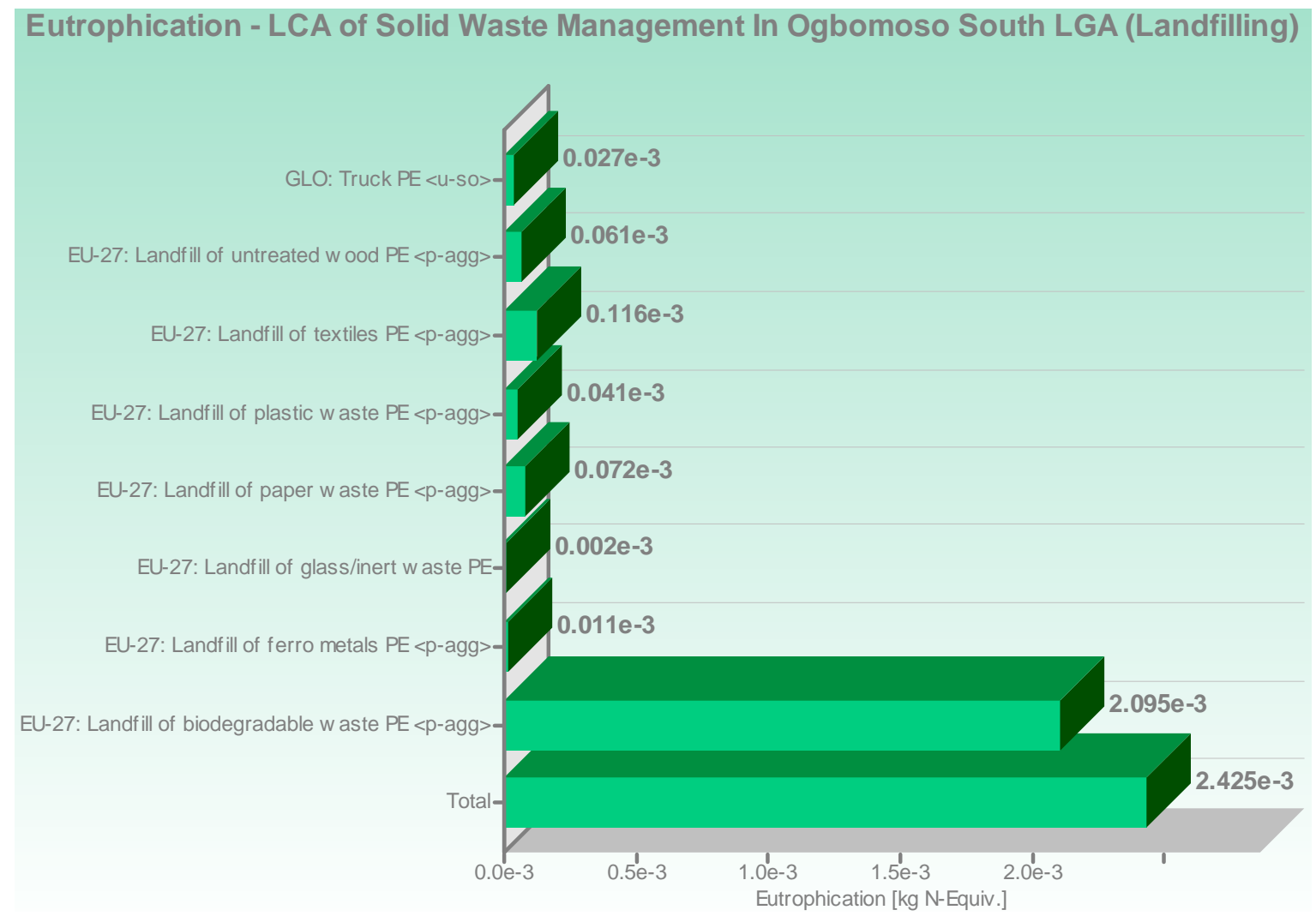

Figure 8. LCIA for landfilling (TRACI-EP).

Ozone Depletion Air - LCA of Solid Waste Management In Ogbomoso South LGA (Landfilling)

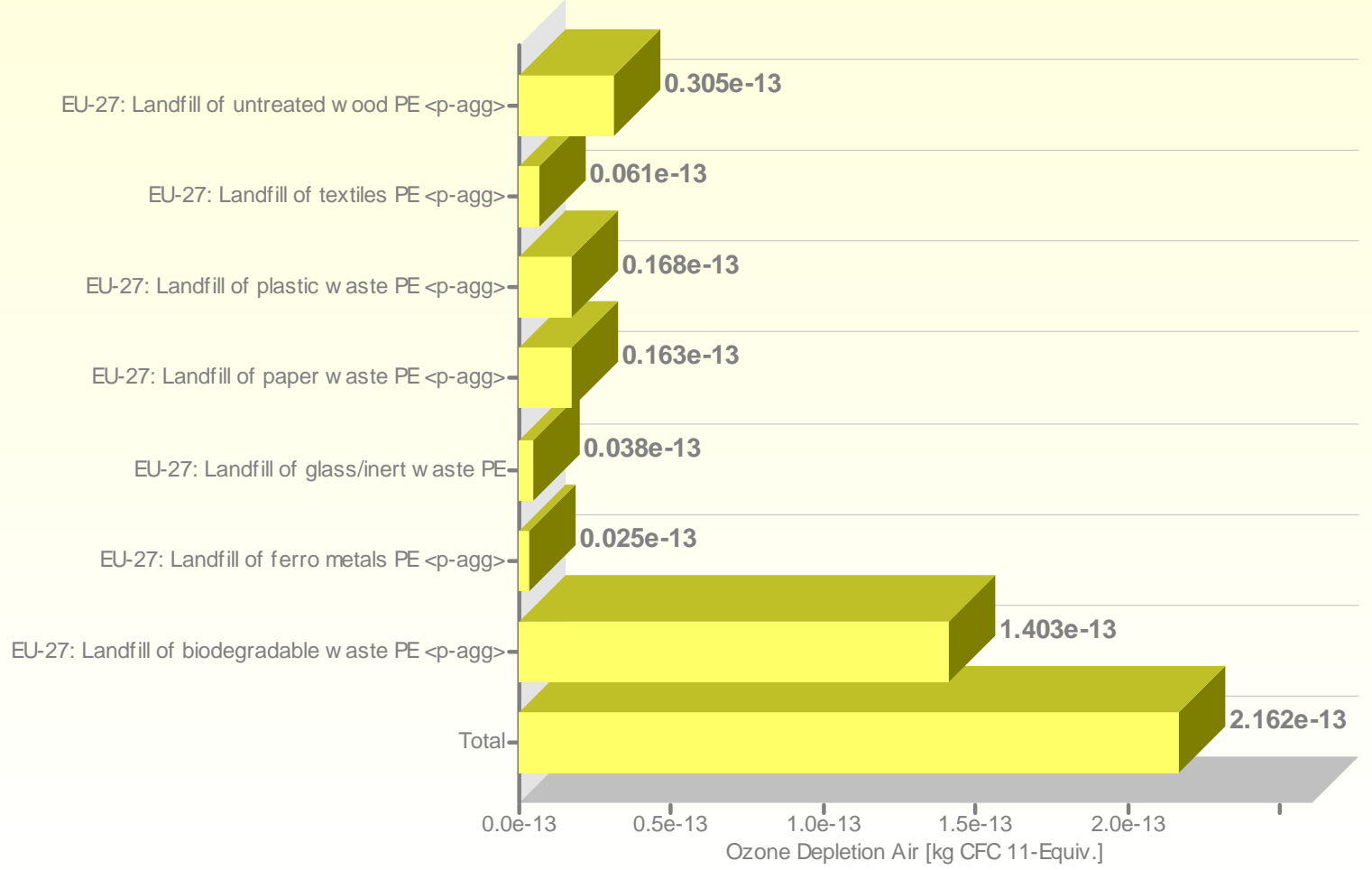

Figure 9. LCIA for landfilling (TRACI-ODP). 


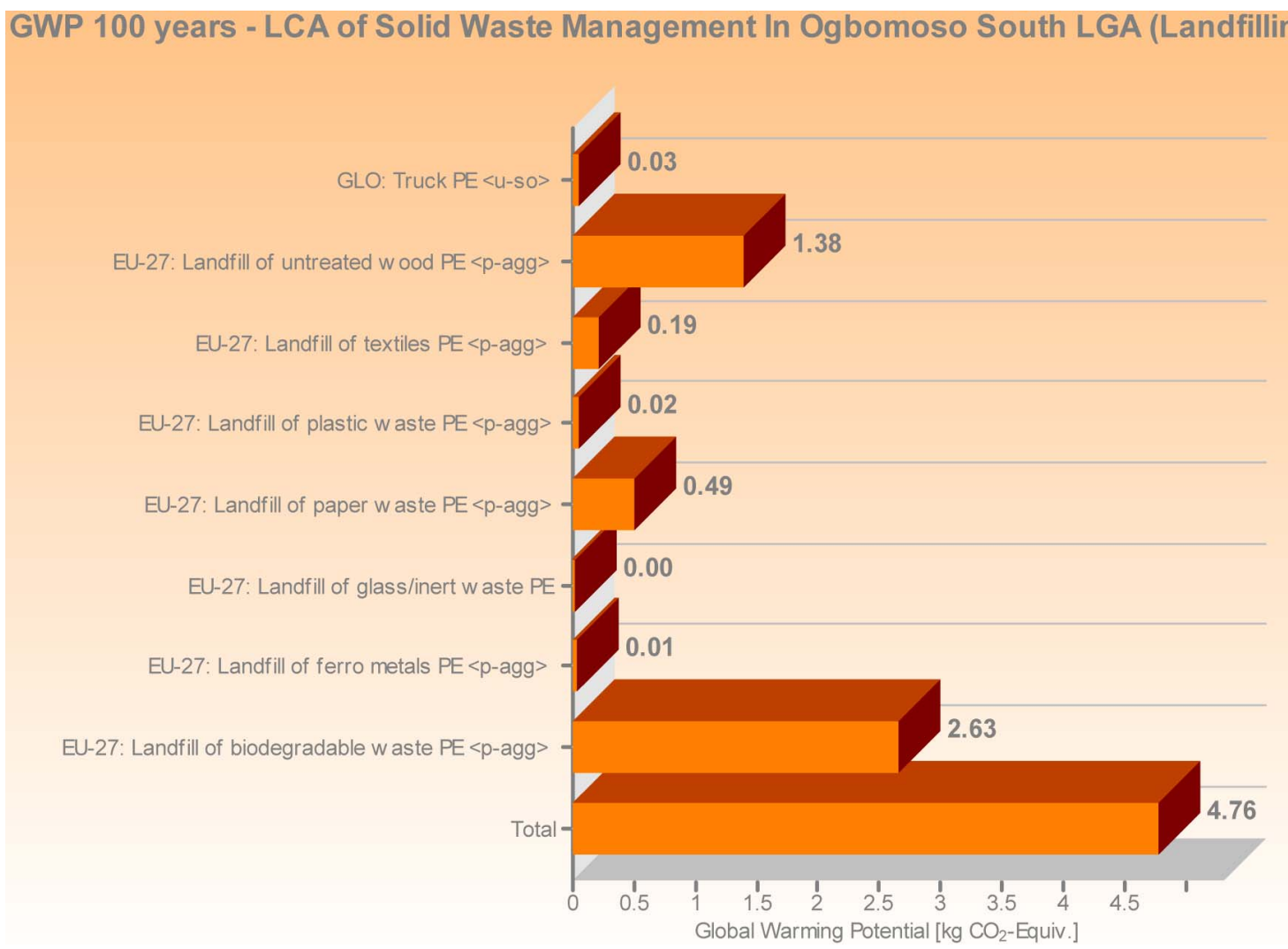

Figure 10. LCIA for landfilling (CML-GWP).

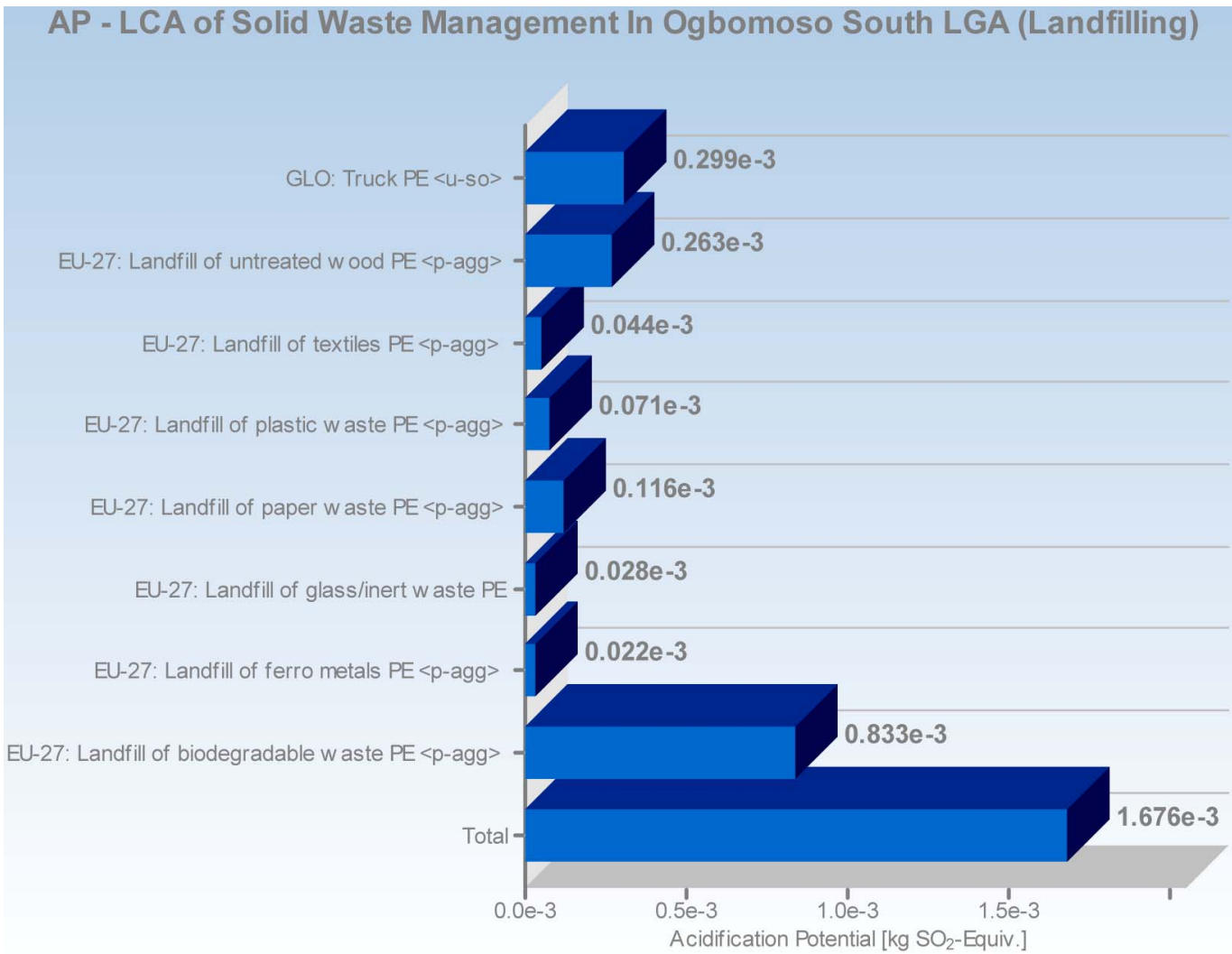

Figure 11. LCIA for landfilling (CML-AP). 


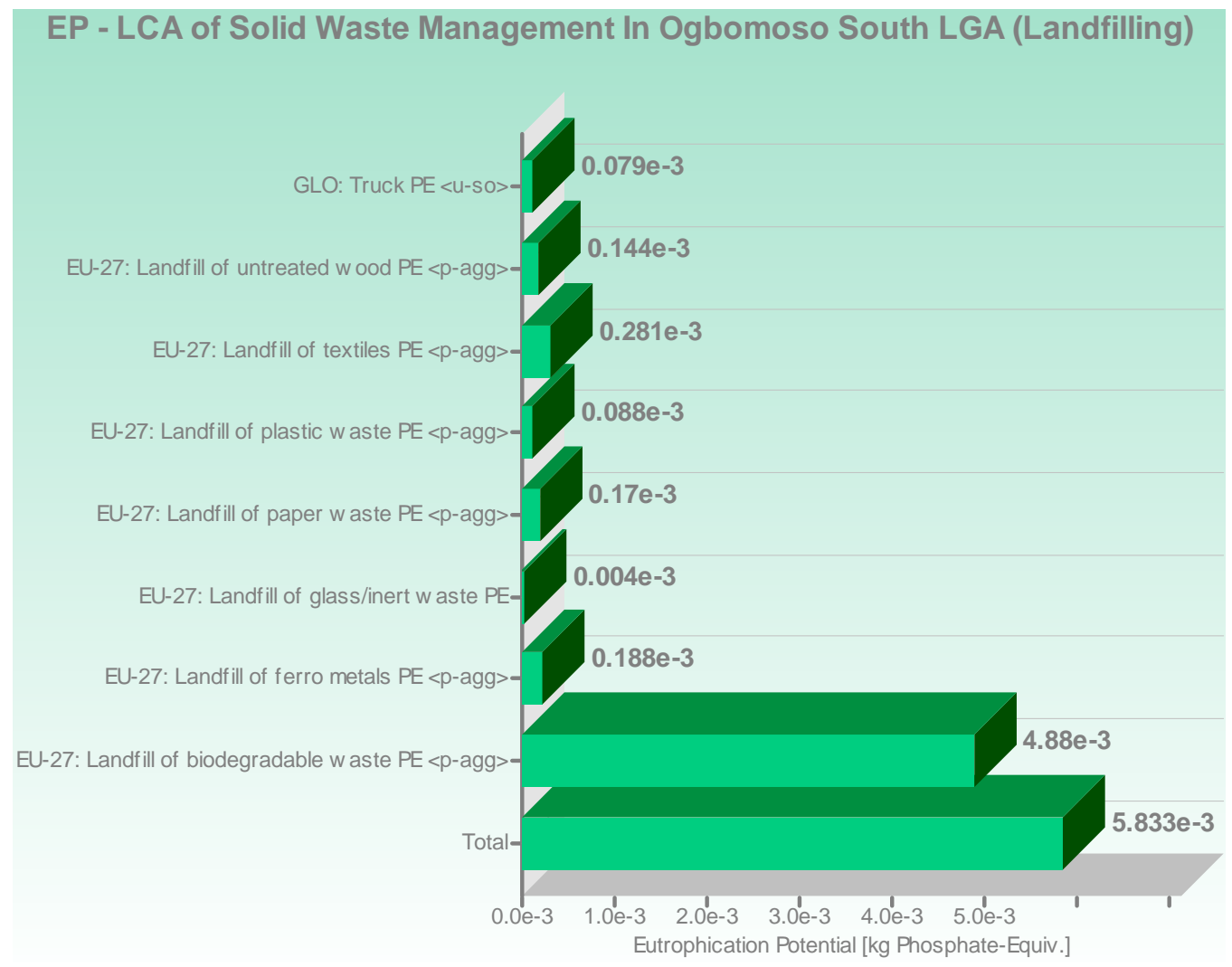

Figure 12. LCIA for landfilling (CML-EP).

ODP, steady state - LCA of Solid Waste Management In Ogbomoso South LGA (Landfi

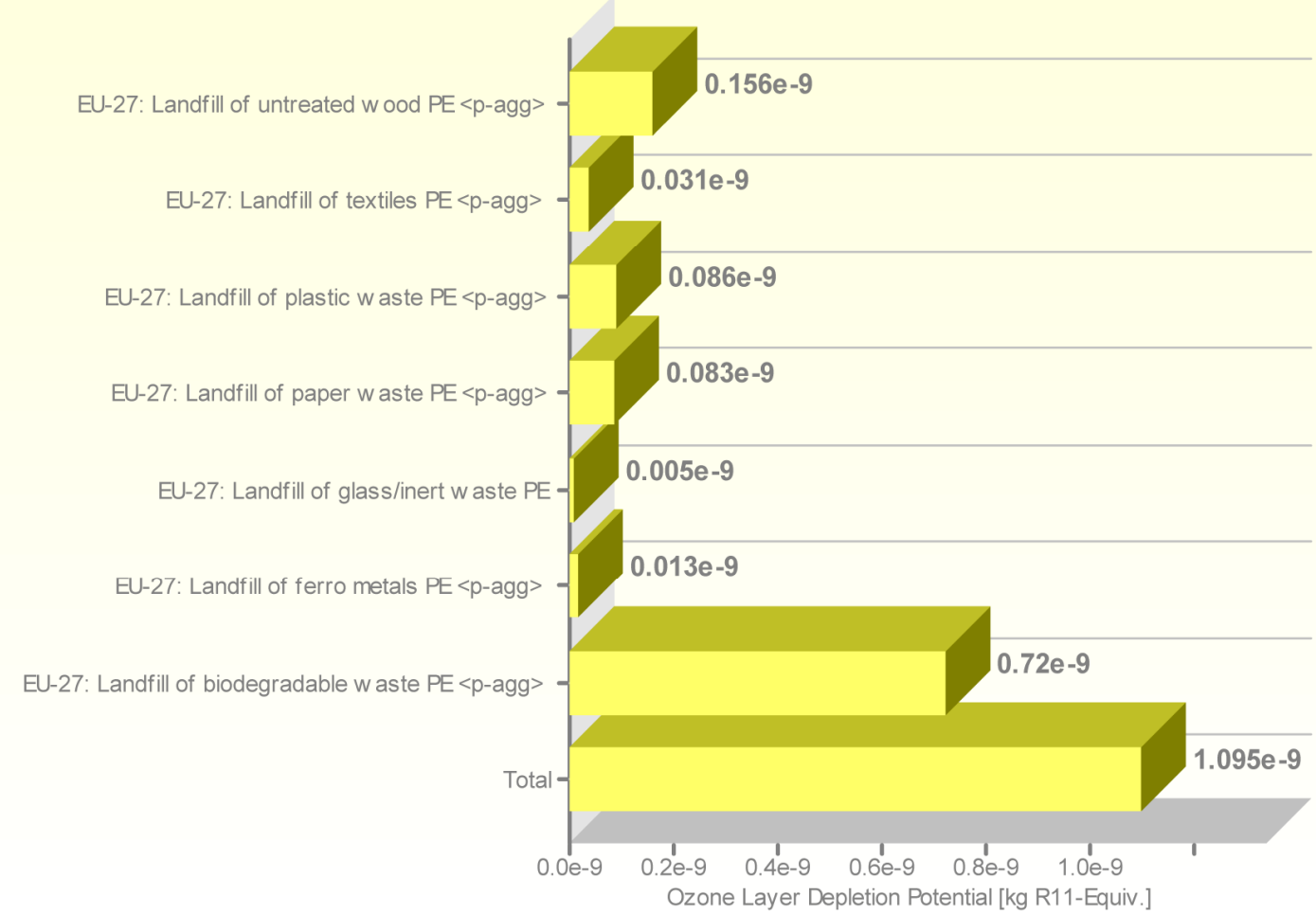

Figure 13. LCIA for landfilling (CML-ODP). 


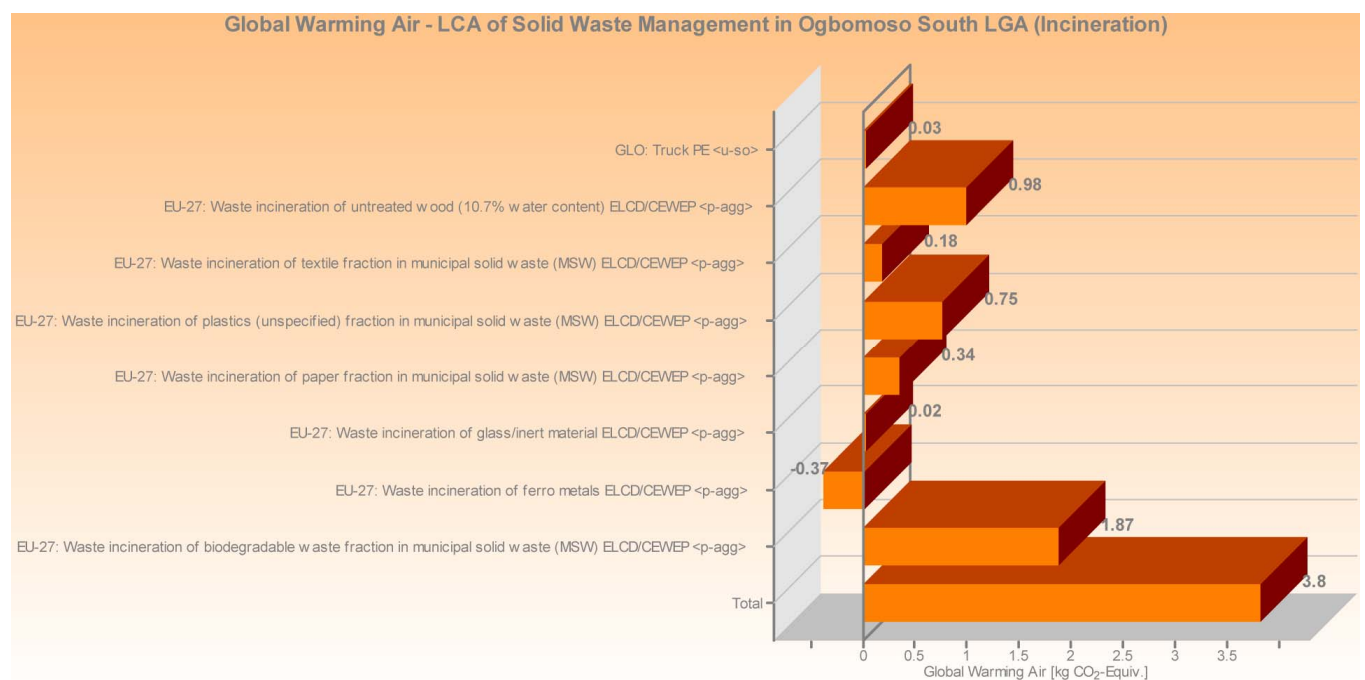

Figure 14. LCIA for incineration (TRACI-GWP).

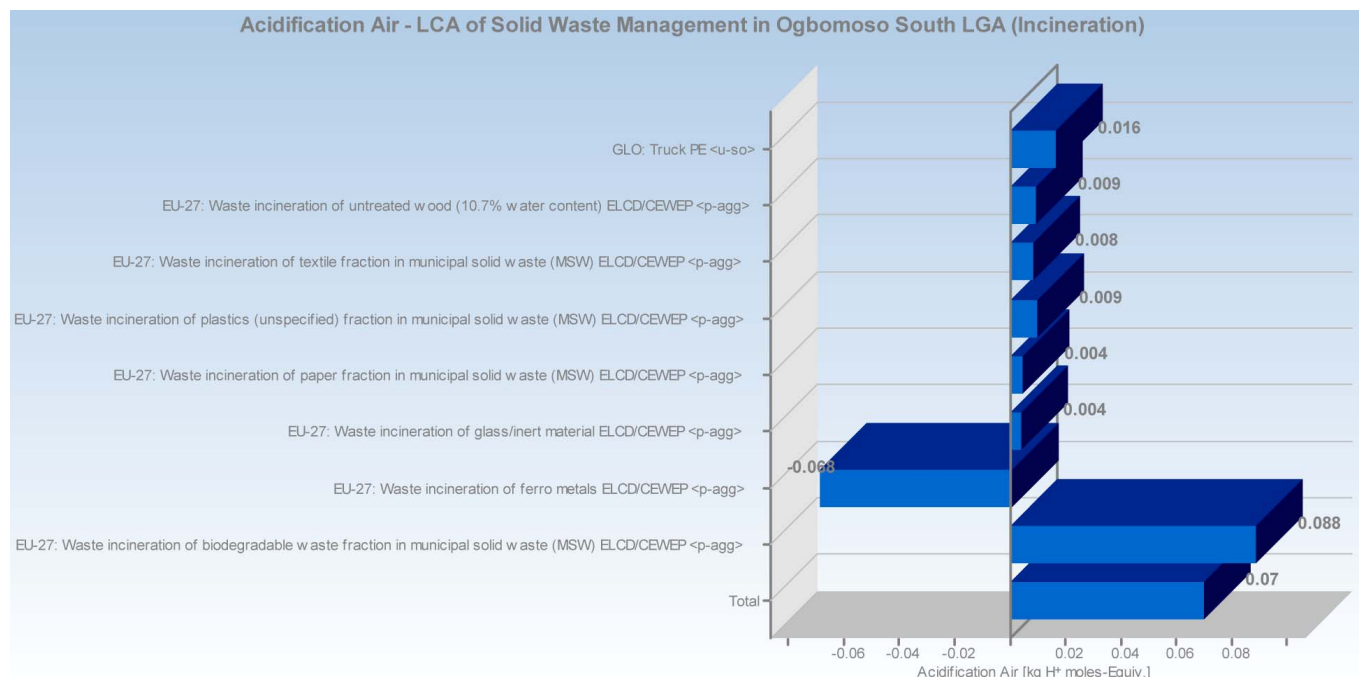

Figure 15. LCIA for incineration (TRACI-AP).

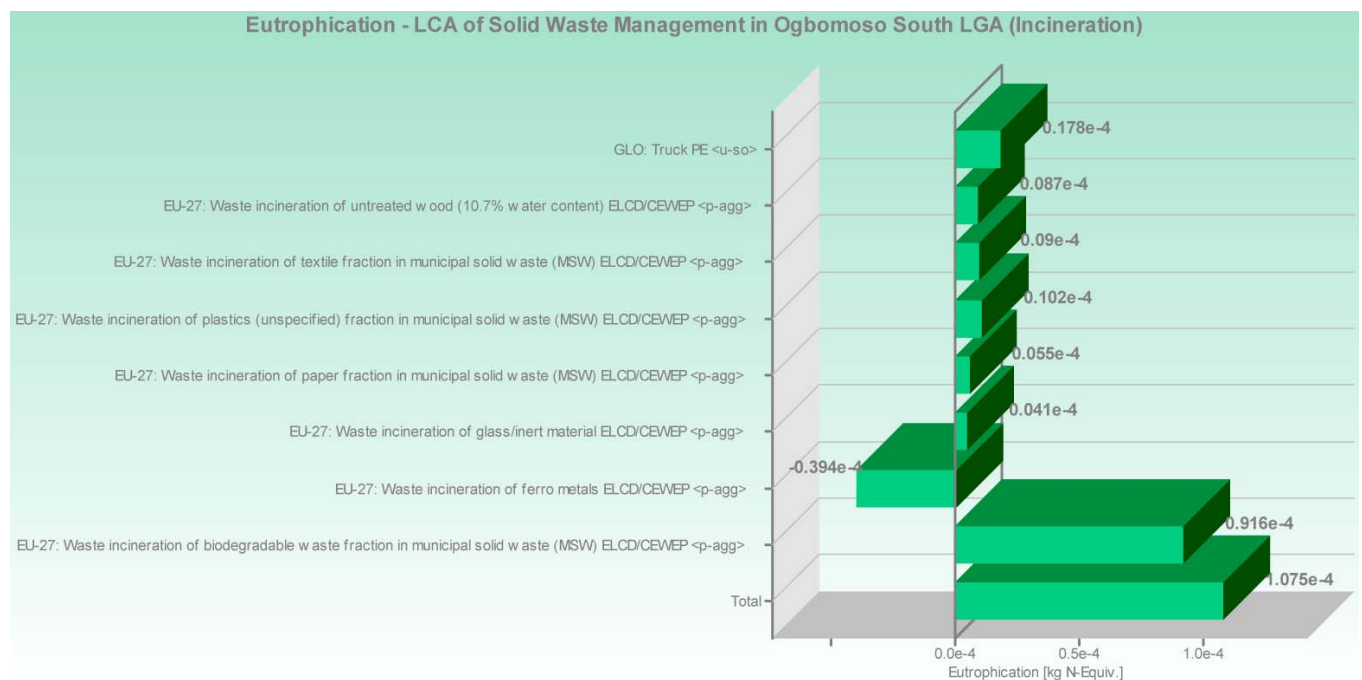

Figure 16. LCIA for incineration (TRACI-EP). 


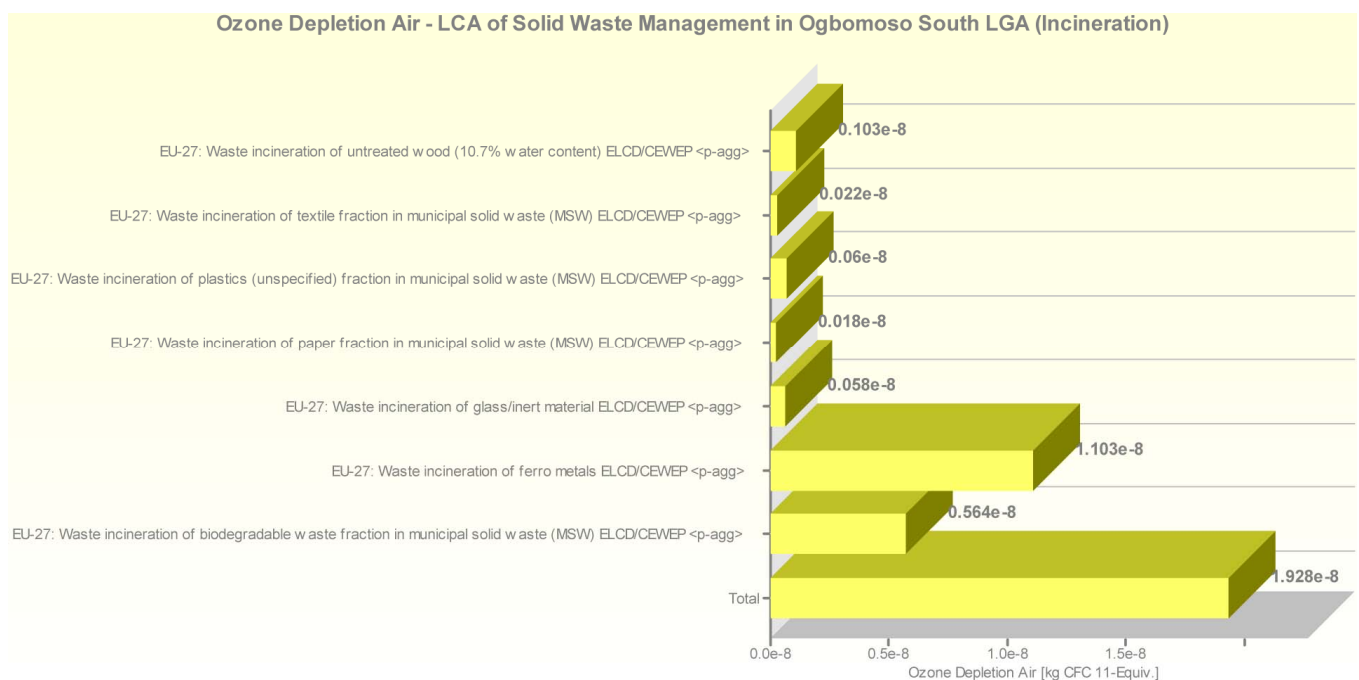

Figure 17. LCIA for incineration (TRACI-ODP).

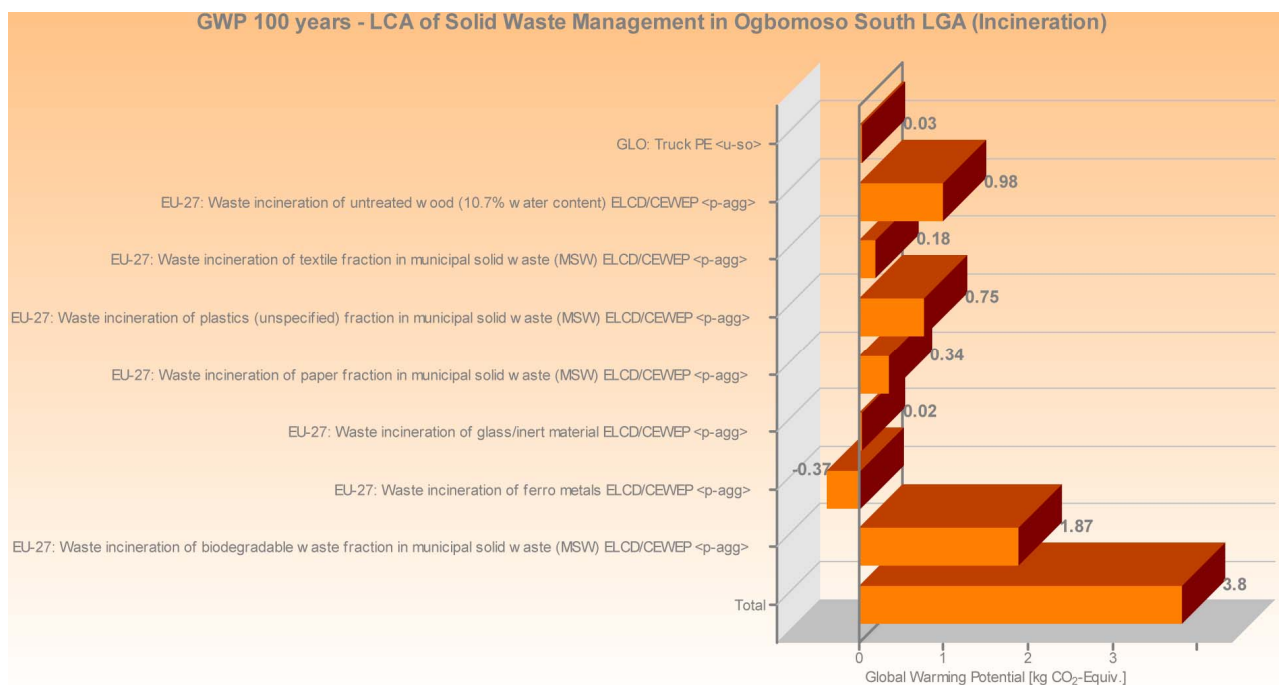

Figure 18. LCIA for incineration (CML-GWP).

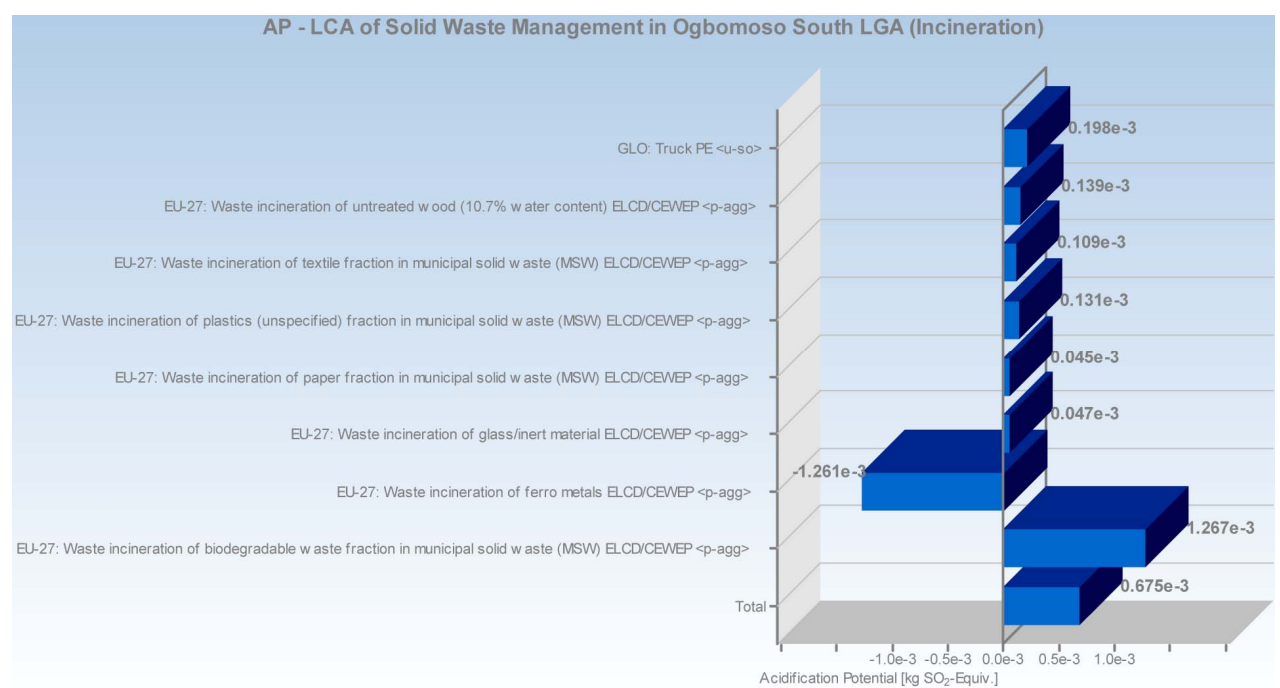

Figure 19. LCIA for incineration (CML-AP). 


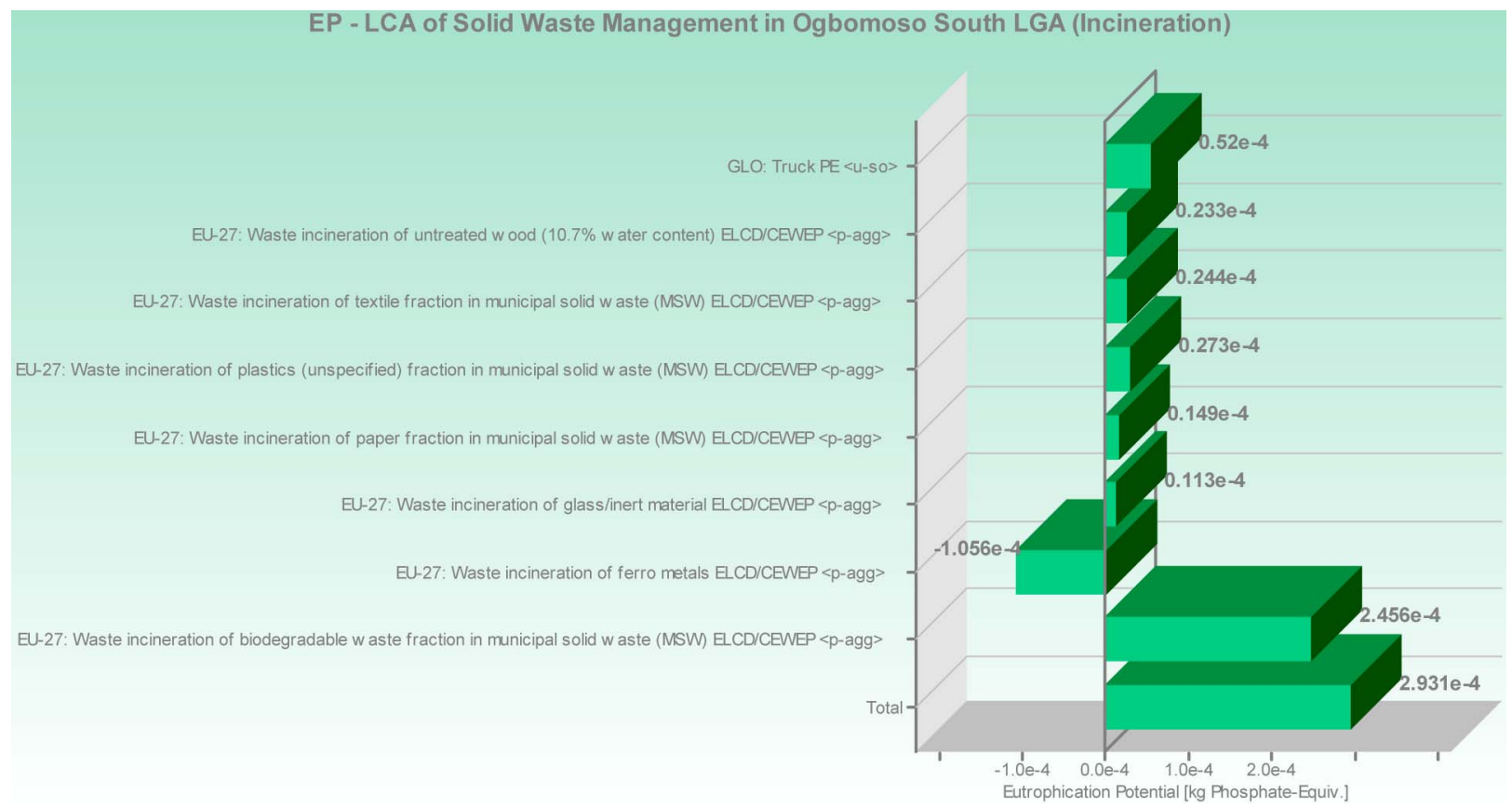

Figure 20. LCIA for incineration (CML-EP).

ODP, steady state - LCA of Solid Waste Management in Ogbomoso South LGA (Incineration)

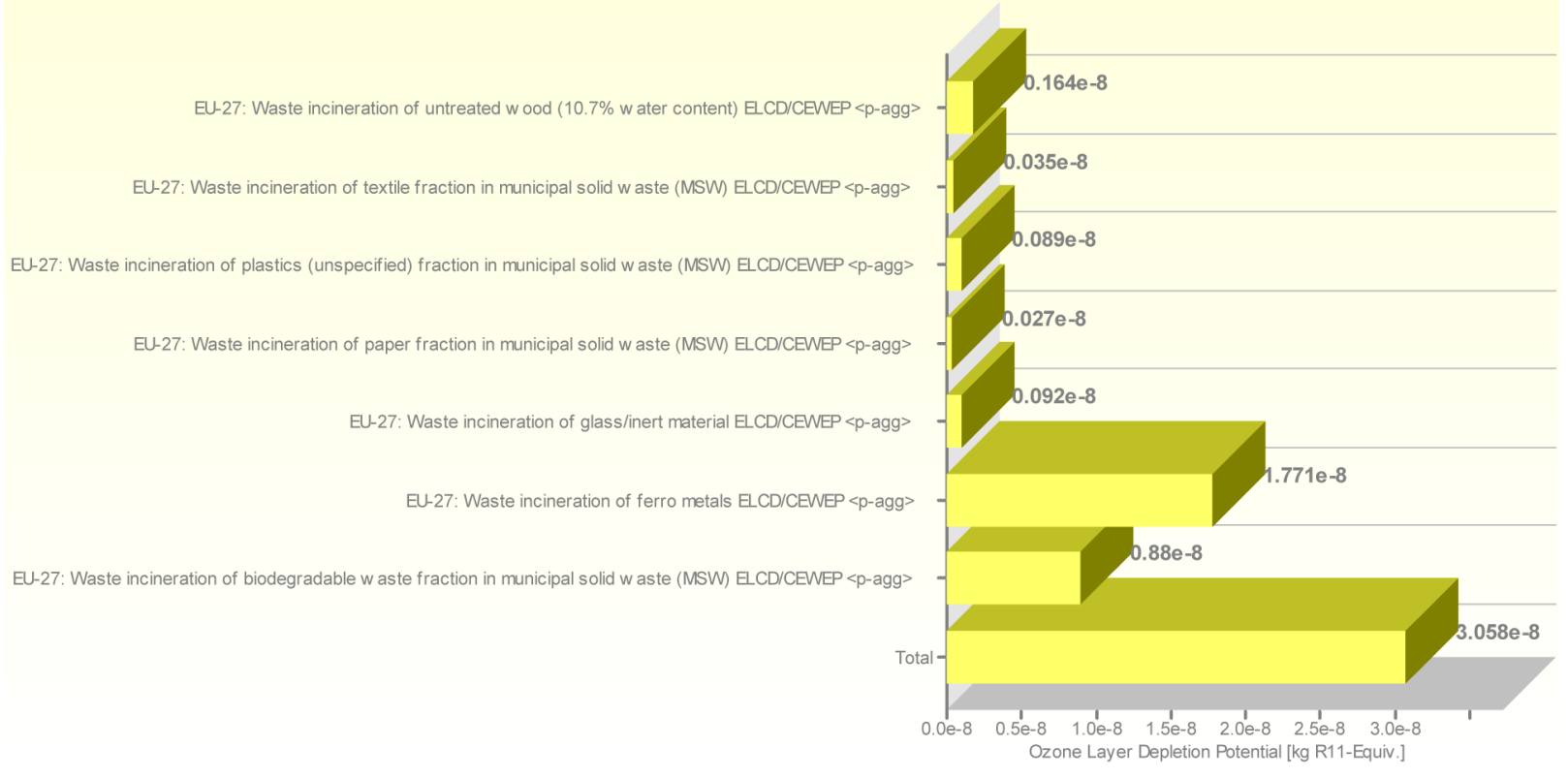

Figure 21. LCIA for incineration (CML-ODP).

Table 6. Summary of the impacts of two scenarios.

\begin{tabular}{ccccc}
\hline \multirow{2}{*}{ Index/LCIA Method } & \multicolumn{2}{c}{ Scenario 1 (Landfilling) } & \multicolumn{2}{c}{ Scenario 2 (Incineration) } \\
\cline { 2 - 5 } & TRACI & CML & TRACI & CML \\
\hline GWP ( $\mathrm{CO}_{2}$ equiv) & 4.76 & 4.76 & 3.7 & 3.8 \\
AP ( $\mathrm{SO}_{2}$ equiv) & 0.11 & $1.676 \mathrm{E}-3$ & 0.07 & $0.67 \mathrm{E}-3$ \\
EP (P equiv) & $4.25 \mathrm{E}-3$ & $5.833 \mathrm{E}-3$ & $1.075 \mathrm{E}-4$ & $2.93 \mathrm{E}-4$ \\
ODP & $2.16 \mathrm{E}-13$ & $1.09 \mathrm{E}-9$ & $1.928 \mathrm{E}-8$ & $3.058 \mathrm{E}-8$ \\
\hline
\end{tabular}




\section{Conclusion}

The average per capita waste being generated in Ogbomoso South LGA stands at $0.49 \mathrm{~kg}$. Biodegradable matters constitute the highest wastes as found from the waste composition study, about $60 \%$. Wastes for incineration from the study area are about a third of the total constituents. From the LCIA using TRACI and CML methods, it is found that landfilling of wastes pose a lesser burden on the environment, using the ODP index, as compared to incineration. It is concluded that of the management scenarios considered, landfilling of wastes is more environmentally friendly and therefore recommended for use in the study area.

\section{REFERENCES}

[1] Franklin Associates, "Product Life-Cycle Assessment: Guidelines and Principles,” EPA Report No. 68-CO-003, 1991.

[2] S. Svoboda, "Notes on Life Cycle Analysis," National Pollution Prevention Centre for Higher Education, University of Michigan Corporate Environmental Management Program, 1995, pp. 1-3.

[3] H. W. Gottinger, "A Computational Model for Solid Waste Management with Application," European Journal of Operational Research, Vol. 35, No. 3, 1988, pp 350-364. doi:10.1016/0377-2217(88)90225-1

[4] M. MacDonald, "Solid Waste Management Models: A State of the Art Review," Journal of Waste Technology and Management, Vol. 23, No. 2, 1996, pp. 73-83.

[5] J. R. Barton, D. Dalley and V. S. Patel, "Life Cycle Assessment for Waste Management," Waste Management, Vol. 16, No. 1-3, 1996, pp. 35-50.

[6] G. Dodbiba, K. Takahashi, J. Sadaki and T. Fujita, "The Recycling of Plastic Wastes from Discarded TV Sets: Comparing Energy Recovery with Mechanical Recycling in the Context of Life Cycle Assessment," Journal of Cleaner Production, Vol. 16, No. 4, 2008, pp. 458-470. doi:10.1016/i.jclepro.2006.08.029

[7] A. Moberg, G. Finnveden, J. Johansson and P. Lind, "Life Cycle Assessment of Energy from Solid Waste-Part 2: Landfilling Compared to Other Treatment Methods," Journal of Cleaner Production, Vol. 13, No. 3, 2005, pp. 231-240. doi:10.1016/j.jclepro.2004.02.025

[8] G. Finnveden, J. Johansson, P. Lind and A. Moberg, "Life Cycle Assessment of Energy from Solid Waste-Part 1: General Methodology and Results," Journal of Cleaner Production, Vol. 13, No. 3, 2005, pp. 213-229. doi:10.1016/j.jclepro.2004.02.023

[9] P. Roy, T. Ijiri, D. Nei, T. Orikasa, H. Okadome, N. Nakamura and T. Shiina, "Life Cycle Inventory (LCI) of Different Forms of Rice Consumed in Households in Japan," Journal of Food Engineering, Vol. 91, No. 1, 2009, pp. 49-55. doi:10.1016/j.jfoodeng.2008.08.005

[10] B. Chen, Z. M. Chen, Y. Zhou, J. B. Zhou and G. Q. Chen, "Energy as Embodied Energy Based Assessment for Local Sustainability of a Constructed Wetland in Beijing," Communications in Nonlinear Science and $\mathrm{Nu}$ merical Simulation, Vol. 14, No. 2, 2009, pp. 622-635. doi:10.1016/j.cnsns.2007.05.035

[11] U. Dahl, C. R. Lind, E. Gorokhova, B. Eklund and M. Breitholz, "Food Quality Effects on Copepod Growth and Development: Implications of Bioassays in Ecotoxicological Tesing," Ecotoxicological and Environmental Safety, Vol. 72, No. 2, 2009, pp. 351-357. doi:10.1016/j.ecoenv.2008.04.008

[12] G. A. Blengini, "Life Cycle of Buildings, Demolition and Recycling Potential: A Case Study in Turin, Italy," Building and Environment, Vol. 44, No. 2, 2009, pp. 319-330. doi:10.1016/j.buildenv.2008.03.007

[13] S. M. Al-Salem and P. Lettieri, "Life Cycle Assessment (LCA) of Municipal Solid Waste Management in the State of Kuwait," European Journal of Scientific Research, Vol. 34, No. 3, 2009, pp. 395-405.

http://www.eurojournals.com/ejsr.htm

[14] S. O. Ojoawo, O. A. Agbede and A. Y. Sangodoyin, "System Dynamics Modeling of Dumpsite Leachate Control in Ogbomosoland, Nigeria," Journal of Environmental Protection, Vol. 3, No. 1, 2012, pp. 120-128. doi:10.4236/jep.2012.31015

[15] M. Abou Najm and M. El-Fadel, "Computer-Based Interface for an Integrated Solid Waste Optimization Model," Environmental Modeling Software, Vol. 19, No. 12, 2004, pp. 1151-1164. doi:10.1016/j.envsoft.2003.12.005

[16] P. Fiorucci, R. Minciardi, M. Robba and R. Sacile, "Solid Waste Management in Urban Areas Development and Application of a Decision Support System," Resources Conservation and Recycling, Vol. 37, No. 4, 2003, pp. 301-328. doi:10.1016/S0921-3449(02)00076-9

[17] P. Haastrup, V. Maniezzo, M. Mattarelli, F. M. Rinaldi, I. Mendes and M. Paruccini, "A Decision Support System for Urban Waste Management," European Journal of Operational Research, Vol. 109, No. 2, 1998, pp. 330341. doi:10.1016/S0377-2217(98)00061-7

[18] N. Chang and S. F. Wang, "A Fuzzy Goal Programming Approach for the Optimal Planning of Metropolitan Solid Waste Management Systems," European Journal of Operational Research, Vol. 99, No. 2, 1997, pp. 303-321. doi:10.1016/S0377-2217(96)00024-0

[19] S. Saheri, M. Aghajani, N. E. A. Basri, N. Z. B. Mahmod and R. A. Begum, "Environmental Assessment of Municipal Solid Waste Disposal Options in Malaysia," Australian Journal of Basic Applied Sciences, Vol. 5, No. 11, 2011, pp. 1069-1073.

[20] J. Hokkanen and P. Salminen, "Choosing a Solid Waste Management System Using Multi-Criteria Decision Analysis," European Journal of Operational Research, Vol. 98, No. 1, 1997, pp. 19-36. doi:10.1016/0377-2217(95)00325-8

[21] PE-International, "Introduction to LCA and Modelling Using GaBi Part 1," 2011, pp. 19-23. http://pe-international.com

[22] Microsoft Encarta Reference Library, "Geographical Location of Ogbomoso South Local Government Area," 
Microsoft Corporation's Encarta Software, 2009.

[23] IITA, "Meteorological Data," A Document of the International Institute of Tropical Agriculture, Ibadan, 2001.

[24] NPC, "Official Gazette for 2006 Population Census," National Population Commision, Abuja.
[25] S. O. Ojoawo, "Management of Leachate Pollution from Dumpsites in Ogbomosoland, Nigeria," Ph.D. Thesis, Faculty of Technology, University of Ibadan, Ibadan, 2009 , p. 5. 